\title{
Pendampingan Pendidik dalam Pengembangan E-Comic Tematik Berbasis Augmented Reality Terintegrasi dengan ICT di KKG Gugus 01 Kecamatan Panti Kabupaten Jember
}

\author{
Rafiantika Megahnia Prihandini ${ }^{*}$, Bea Hana Siswati ${ }^{2}$ \\ Universitas Jember, J1. Kalimantan II/24, Kampus Bumi Tegal Boto, Jember, Jawa Timur ${ }^{1}$ \\ Email: rafiantikap.fkip@unej.ac.id ${ }^{1 *}$
}

(Diajukan: 03 September 2021, Direvisi: 15 September 2021, Diterima: 03 November 2021)

\begin{abstract}
ABSTRAK
Satu tahun lebih dunia pendidikan menghadapi tantangan yang cukup besar ditengah mewabahnya virus Covid-19. Pembelajaran yang seharusnya dilaksanakan secara tatap muka tidak bisa lagi dilaksanakan karena bisa memicu proses penyebaran virus Covid-19 yang semakin luas. Hal ini menyebabkan pembelajaran online menjadi satu-satunya alternatif model pembelajaran di masa pandemi Covid-19. Sebagai sesuatu yang baru, tentunya pendidik serta peserta didik harus bisa beradaptasi dengan keadaan tersebut. Kemampuan penguasan teknologi pendidik dalam masa adaptasi kebiasan baru sangat diperlukan. Sehingga, tim pengabdian masyarakat melaksanakan kegiatan pendampingan pendampingan pendidik dalam pegembangan media pembelajaran berupa E-Comic tematik berbasis augmented reality terintegrasi dengan ICT di KKG Gugus 01 Desa Panti Kecamatan Panti Kabupaten Jember. Hasil dari pengabdian ini adalah pendidik mampu mengembangkan media pembelajaran berupa $E$-comic yang terintegrasi dengan ICT. E-comic yang terintegrasi dengan ICT dapat memudahkan mahasiswa dalam memahami materi yang disampaikan oleh pendidik. Hal ini merupakan salah satu upaya dalam mempertahankan kualitas penyampaian materi pelajaran di masa pandemi Covid-19. Hasil kuesioner dari pelaksanaan kegiatan pendampingan pendidik dalam pegembangan E-Comic tematik berbasis augmented reality terintegrasi dengan ICT adalah 35,5\% cukup mahir, 38,7\% mahir, dan $25,8 \%$ sangat mahir dalam membuat media pembelajaran interaktif berupa E-comic dengan aplikasi online maupun offline.
\end{abstract}

Kata kunci: E-Comic, Augmented Reality, ICT.

\begin{abstract}
For more than a year, the considerable challenges as the effect of the Covid-19 outbreak virus has been faced by the education system. Learning process which normally should be carried out face-to-face can no longer be carried out because it can trigger the process of spreading the Covid-19 virus getting wider. For avoiding the spreading of Covid 19, online learning can be applied as the alternative of learning model during the Covid19 pandemic. As something new, of course, educators and students must be able to adapt to these conditions. The ability of mastering the technology for educators in the adaptation period as a new habits is very important. Thus, the community service team carried out mentoring activities for mentoring educators in the development of learning media in the form of augmented reality-based thematic E-Comic integrated with ICT in KKG Gugus 01 Panti Village, Panti District, Jember Regency. Hopefully, the result of this program can guide the teachers developed a learning media in the form of E-comic integrated with ICT. E-comic integrated with ICT can make students easier to understand the material presented by educators. This is one of the efforts to maintain the quality education during the Covid-19 pandemic. The results of the questionnaire from the implementation of mentoring activities for educators in the development of thematic E-Comic based on augmented reality integrated with ICT are $35.5 \%$ quite proficient, $38.7 \%$ proficient, and $25.8 \%$ very proficient in making interactive learning media in the form of E-comic with online and offline applications.
\end{abstract}

Keywords: E-Comic, Augmented Reality, ICT. 


\section{PENDAHULUAN}

Indonesia tengah mengalami tantangan yang cukup besar di tengah mewabahnya virus Covid-19. Virus Covid-19 hampir memberi dampak bagi seluruh aspek, salah satunya adalah aspek pendidikan. Perubahan ini membuat pemerintah hanya memiliki satu kebijakan agar proses pembelajaran tetap bisa berjalan meskipun sedang ada di masa yang sulit. Kebijakan tersebut adalah pelaksanaan pembelajaran secara online. Model pembelajaran secara online, diharapkan mampu menekan perkembangan virus Covid-19. Model pembelajaran ini tentunya akan memberi dampak pula bagi pendidik, peserta didik, maupun fasilitas pendidikan. Pendidik maupun peserta didik harus mampu beradaptasi dengan model pembelajaran online. Pendidik dituntut terampil menggunakan perangkat lunak dalam mengembangkan model maupun media pembelajaran. Pembelajaran online merupakan hal baru yang dialami oleh pendidik maupun peserta didik sehingga akan terdapat berbagai kendala dalam proses pelaksanaannya. Dalam praktik pelaksanaan pembelajaran online, keterbatasan pendidik dalam pemanfaatan teknologi, ketersediaan sarana dan prasarana seperti hanadphone maupun perangkat komputer, harus bisa diatasi sebagai upaya peserta didik dapat menerima materi pelajaran secara maksimal.

Ujung tombak dalam pembelajaran online adalah pendidik sehingga pendidik harus mampu mengupayakan pembelajaran secara maksimal baik menggunakan media Group Whatsaap, Edmodo, Google Classroom, Google Meet, dan Zoom Cloud Meeting. Pendidik mengolah pemanfaatan berbagai media pembelajaran online sesuai dengan keinginan dan kemampuan pendidik. Namun hal yang disampaikan pendidik melalui media tersebut harus tetap inovatif dan kreatif sehingga peserta didik tidak merasa bosan selama proses pembelajaran. Keterampilan guru dalam mengembangkan media pembelajaran menjadi salah satu penentu keberhasilan pembelajaran online.

Perkembangan media pembelajaran sejalan dengan berkembangnya teknologi. Media pembelajaran yang dihasilkan menjadi semakin ringkas dan menarik tanpa mengurangi esensi dari materi. Salah satu perkembangan media pembelajaran yang saat ini masih baru adalah media pembelajaran berbasis Augmented Reality. Penggabungan dunia nyata dan dunia maya yang disajikan dalam bentuk 2D maupun 3D, merupakan dasar dari Augmented Reality. Augmented Reality bisa menjadi salah satu alternatif media pembelajaran yang menarik karena siswa dapat memahami suatu permasalahan melalui benda - benda yang biasa mereka lihat dalam kehidupan sehari - hari. 
Beberapa penelitian terkait dengan Augmented Reality dan pengembangan E-Comic sebagai media pembelajaran interaktif antara lain ditulis oleh Mohd Ekram Al Hafis Bin Hashim et al menyimpulkan bahwa perkembangan teknologi Augmented Reality yang pesat telah mengembangkan kajian di berbagai bidang. Salah satunya adalah bidang teknologi yang memproduksi berbagai produk kreatif. Melalui kajian teori dan model Augmented Reality serta pendekatan UX, dapat menghasilkan sebuah komik Augmented Reality yang memiliki kerangka kerja teoritis.

Penelitian tentang Augmented Reality Comic Book dilatar belakangi oleh data tentang minat baca siswa di Indonesia yang rendah, jumlah peminat komik di Indonesia yang signifikan, serta pemanfaatan teknologi Augmented Reality dalam dunia pendidikan. Melalui penelitian yang telah dilaksanakan oleh Dwi Wahyu Widiastuti dapat disimpulkan bahwa penggunaan media pembelajaran dalam bentuk augmented realitycomic book dapat memberikan pengalaman belajar yang baru bagi pebelajar melalui isi cerita yang menarik, visualisasi benda 3D pada comic book, dan penggunaan suara.

Selain dari kedua penelitian diatas terdapat penelitian sebelumnya yaitu mengenai Pengembangan Game Edukasi Mobile Augmented Reality untuk Membantu Pembelajaran Anak dalam Membaca, Menulis, dan Berhitung. Dalam penelitian ini disimpulkan bahwa Penggunaan augmented reality pada game Animal Quiz menjadi salah satu faktor yang membuat responden merasa tertarik untuk bermain dengan game Animal Quiz. Siswa merasa mudah untuk menggunakan teknologi augmented reality dan siswa merasa mudah melihat obyek yang ditampilkan di atas marker, mereka mampu mengenali hewan-hewan dan mengetahui nama dari hewan-hewan tersebut.

Berdasarkan beberapa penelitian sebelumnya, tim pengabdian ingin mengkombinasikan Augmented Reality melalui pengembangan E-Comic. Hal ini juga didukung oleh kondisi dan situasi yang dituju sebagai tempat pelaksanaan pengabdian. Sekolah Dasar di KKG Gugus 01 Desa Panti Kecamatan Panti Kabupaten Jember merupakan salah satu KKG (Kelompok Kerja Guru) yang berada di kaki gunung Argopuro. KKG Gugus 01 Desa Panti Kecamatan Panti Kabupaten Jember terdiri dari lima sekolah dasar, dengan jumlah pendidik sekitar 60 pendidik. Kondisi yang jauh dari kota membuat pendidik hanya memanfaatkan buku paket dalam proses pembelajaran. Media yang digunakan hanya seadanya tanpa ada inovasi. Permasalahan tersebut dapat diselesaikan secara tepat dan cepat, sehingga proses pembelajaran yang terintegrasi dengan ICT dapat terlaksana dengan baik melalui pendampingan dalam mengembangkan E-Comic tematik 
berbasis Augmented Reality terintegrasi dengan ICT bagi pendidik KKG Gugus 01 Desa Panti Kecamatan Panti Kabupaten Jember.

Beberapa kondisi pendidik KKG Gugus 01 Desa Panti Kecamatan Panti Kabupaten Jember, antara lain (1) lokasi jauh dari kota sehingga menyebabkan beberapa pendidik kurang termotivasi untuk mengikuti kegiatan ilmiah yang mendukung proses pembelajaran, (2) kurangnya pemanfaatan internet dalam pemahaman tentang pengembangan perangkat dan media pembelajaran, dan (3) jarangnya dilakukan pelatihan-pelatihan di KKG Gugus 01 pengintegrasian budaya dalam proses pembelajaran.

Dari hasil observasi yang dilakukan oleh tim pengabdian, pembelajaran di KKG Gugus 1 Desa Panti Kecamatan Panti dilaksanakan dengan cara menggunakan metode ceramah, tanya jawab, diskusi, demonstrasi, membaca teks, dan membuat ringkasan. Media yang digunakan saat pembelajaran antara lain media power point, media cetak, dan hanya melampirkan link video dari Youtube. Media pembelajaran tersebut membuat peserta didik kesulitan dalam memahami konsep - konsep materi yang disajikan sehingga akan berdampak pada kesulitan dalam penerapan konsep - konsep yang tepat. Pembelajaran online yang cenderung monoton ini membuat minat membaca materi pelajaran peserta didik rendah. Sebagai salah satu alternatif dalam mengatasi masalah tersebut adalah pembuatan E-Comic. Penggunaan E-Comic diharapkan mampu memotivasi anak untuk belajar melalui contoh cerita yang ada dalam komik tersebut. Keunggulan dari pengembangan media $E$ Comic antara lain dapat menghemat biaya, mudah dalam penyimpanan atau pengarsipannya, lebih praktis untuk dibawa-bawa dan lebih awet dibandingkan dengan media kertas.

\section{METODE}

Solusi permasalahan yang dihadapi sekolah dasar anggota KKG Gugus 01 Desa Panti Kecamatan Panti Kabupaten Jember adalah dilakukan pendampingan bagi pendidikpendidik dalam mengembangkan media pembelajaran E-Comic tematik berbasis augmented reality terintegrasi dengan ICT. Sehubungan dengan permasalahan yang dihadapi pendidik KKG Gugus 01 Desa Panti Kecamatan Panti Kabupaten Jember, solusi yang ditawarkan oleh tim pengabdian adalah pendampingan dengan menerapkan prosedur ADDIE. Model ini, terdiri dari lima tahap utama, yaitu (A)nalysis, (D)esain, (D)evelopment, (I)mplementation, dan (E)valuation. Selanjutnya model ini dimodifikasi dalam pelaksanaan pengabdian. Model ADDIE sendiri adalah sebuah aktivitas pembelajaran yang memiliki karakter interaktif dengan beberapa langkah dasar pembelajaran yang efisien, dinamis dan efektif. Model ADDIE bisa menjadi panduan untuk mengembangkan sebuah instrumen dan 
fasilitas strategi pembelajaran yang efisien, dinamis dan efektif untuk membantu performa pembelajaran.

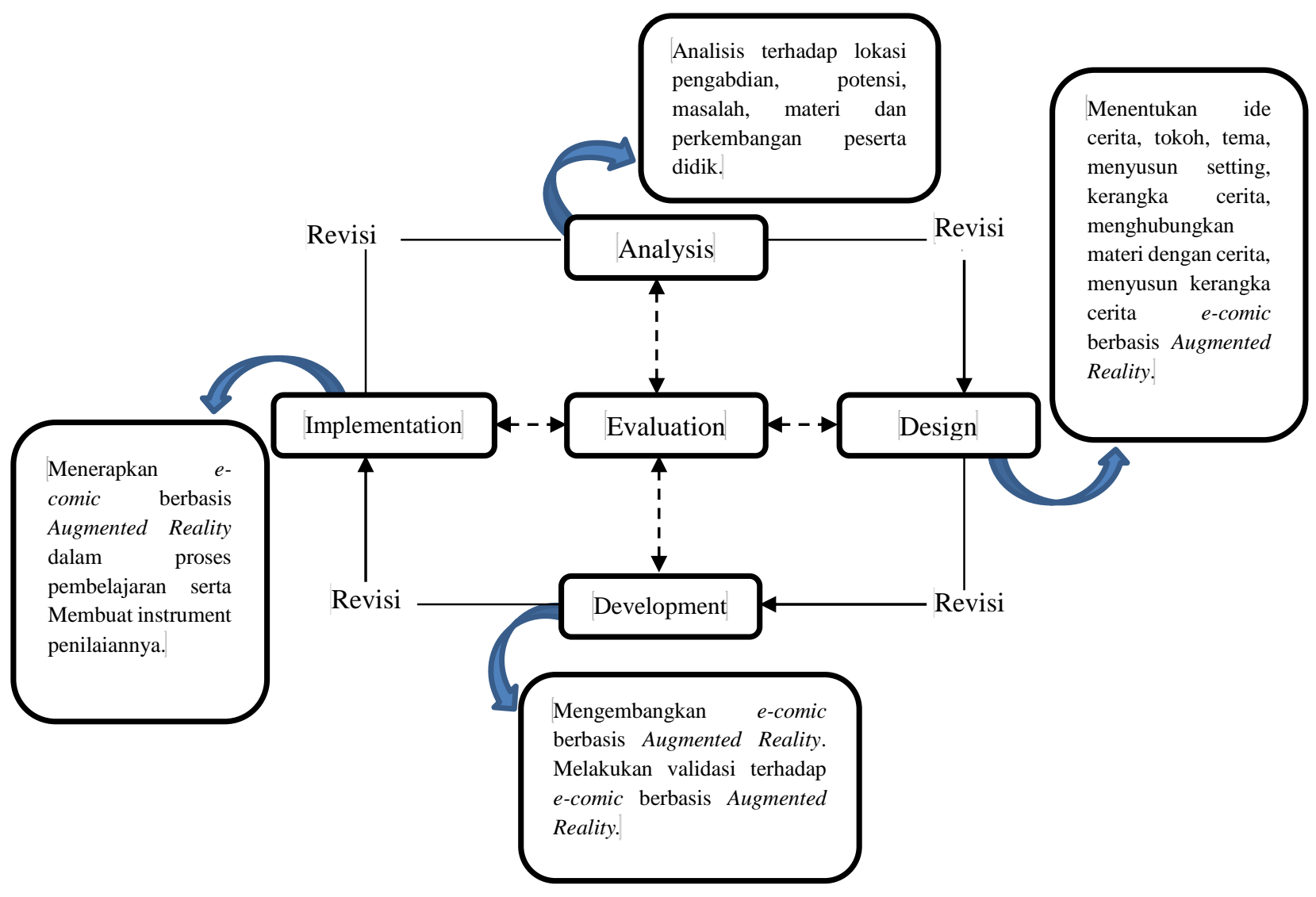

Gambar 1. Pemanfaatan Model ADDIE (Analysis, Design, Development, Implementation dan Evaluations).

\section{HASIL, PEMBAHASAN, DAN DAMPAK}

Pengabdian dilaksanakan dengan mengadopsi metode ADDIE. Model ini, terdiri dari lima tahap utama, yaitu (A)nalysis, (D)esain, (D)evelopment, (I)mplementation, dan (E)valuation. Tahap Analysis, pada tahap ini diperoleh informasi bahwa pembelajaran di KKG Gugus 1 Desa Panti Kecamatan Panti dilaksanakan dengan cara menggunakan metode ceramah, tanya jawab, diskusi, demonstrasi, membaca teks, dan membuat ringkasan yang kemudian dikumpulkan melalui whatsapp group. Media yang digunakan saat pembelajaran antara lain media power point, media cetak, dan hanya menautkan link video dari Youtube. Media pembelajaran tersebut membuat peserta didik kesulitan dalam memahami konsep konsep materi yang disajikan sehingga akan berdampak pada kesulitan dalam penerapan konsep - konsep yang tepat. Pembelajaran online yang cenderung monoton ini membuat minat membaca materi pelajaran peserta didik rendah. Sebagai salah satu alternatif dalam 
mengatasi masalah tersebut adalah pembuatan E-Comic. Penggunaan E-Comic diharapkan mampu memotivasi anak untuk belajar melalui contoh cerita yang ada dalam komik tersebut.

Selanjutnya berdasarkan tahap analysis, maka dilakukan tahap design. Pada tahap ini, tim pengabdian melakukan beberapa hal antara lain: Memberikan penjelasan dan contoh ide cerita yang sesuai dengan peristiwa di sekitar sekolah melalui pendekatan tematik berbasis Augmented Reality dan selanjutnya pendidik diberi kesempatan untuk menentukan ide cerita, Memberikan penjelasan dan contoh tokoh yang sesuai cerita yang akan dikembangkan dan selanjutnya pendidik diberi kesempatan untuk menentukan tokoh, Memberikan penjelasan dan contoh tema yang sesuai materi pelajaran tematik berbasis Augmented Reality dan selanjutnya pendidik diberi kesempatan untuk menentukan tema, Memberikan penjelasan dan contoh setting yang sesuai dengan peristiwa yang dipilih dan selanjutnya pendidik diberi kesempatan untuk menyusun setting, Memberikan penjelasan dan contoh kerangka cerita yang sesuai dengan tema yang dipilih dan selanjutnya pendidik diberi kesempatan untuk menyusun kerangka cerita, dan Memilih mata pelajaran yang akan dikembangkan menjadi E-Comic tematik berbasis Augmented Reality terintegrasi dengan ICT.

Tahap development, pada tahap ini tim pengabdian melakukan beberapa hal antara lain: Memberikan penjelasan mengenai pentingnya validasi media pembelajaran, Memberikan penjelasan mengenai instrument validasi, Membuat E-Comic tematik berbasis Augmented Reality terintegrasi dengan ICT, Membuat Buku Panduan Pembuatan E-Comic tematik berbasis Augmented Reality terintegrasi dengan ICT. Buku panduan tersebut dapat diakses secara online melalui link : https://unej.id/BukuPanduanEComic. Materi pelajaran yang dipilih untuk kemudian dikembangkan menjadi Membuat E-Comic tematik berbasis Augmented Reality adalah materi bidang datar. Materi ini dipilih karena pembelajaran geometri tentang sifat-sifat bangun datar sangat kurang begitu memuaskan. Dari analisis evaluasi hasil belajar yang dilakukan tim pengabdian menemukan bahwa rendahnya hasil belajar ketiga siswa tersebut dikarenakan siswa tidak memahami materi geometri tentang sifat-sifat bangun datar. Pengembangan E-Comic tematik berbasis Augmented Reality terintegrasi dengan ICT, diharapkan mampu meningkatkan pemahaman siswa mengenai materi bidang datar.

Tahap implementation, pada tahap ini tim pengabdian menyampaikan materi mengenai pembuatan E-Comic tematik berbasis Augmented Reality terintegrasi dengan ICT dalam proses pembelajaran serta membagikan buku panduan dan E-Comic kepada peserta pendampingan. Adapun metode pendampingan yang dipilih adalah belajar mandiri dan 
pembelajaran terprogram. Melalui pembelajaran mandiri dengan disertai pegangan berupa panduan yang disusun secara rinci dan sistematik, diharapkan peserta pendampingan bisa lebih mudah memahami dan menerapkan materi yang disampaikan pada kegiatan pendampingan. Pembuatan E-Comic menggunakan aplikasi online yaitu Canva. Canva adalah sebuah tools untuk desain grafis yang menjembatani penggunanya agar dapat dengan mudah merancang berbagai jenis desain kreatif secara online. Mulai dari mendesain kartu ucapan, poster, brosur, infografik, hingga presentasi. Canva saat tersedia dalam beberapa versi, web, iPhone, dan Android. E-Comic yang dihasilkan kemudian dikembangkan kembali menjadi format apk dengan menggunakan aplikasi online appgeyser sehingga bisa diunduh pada Playstore. Berikut adalah tampilan komik yang dikembangkan dan tampilan E-Comic yang telah di publish di Playstore.
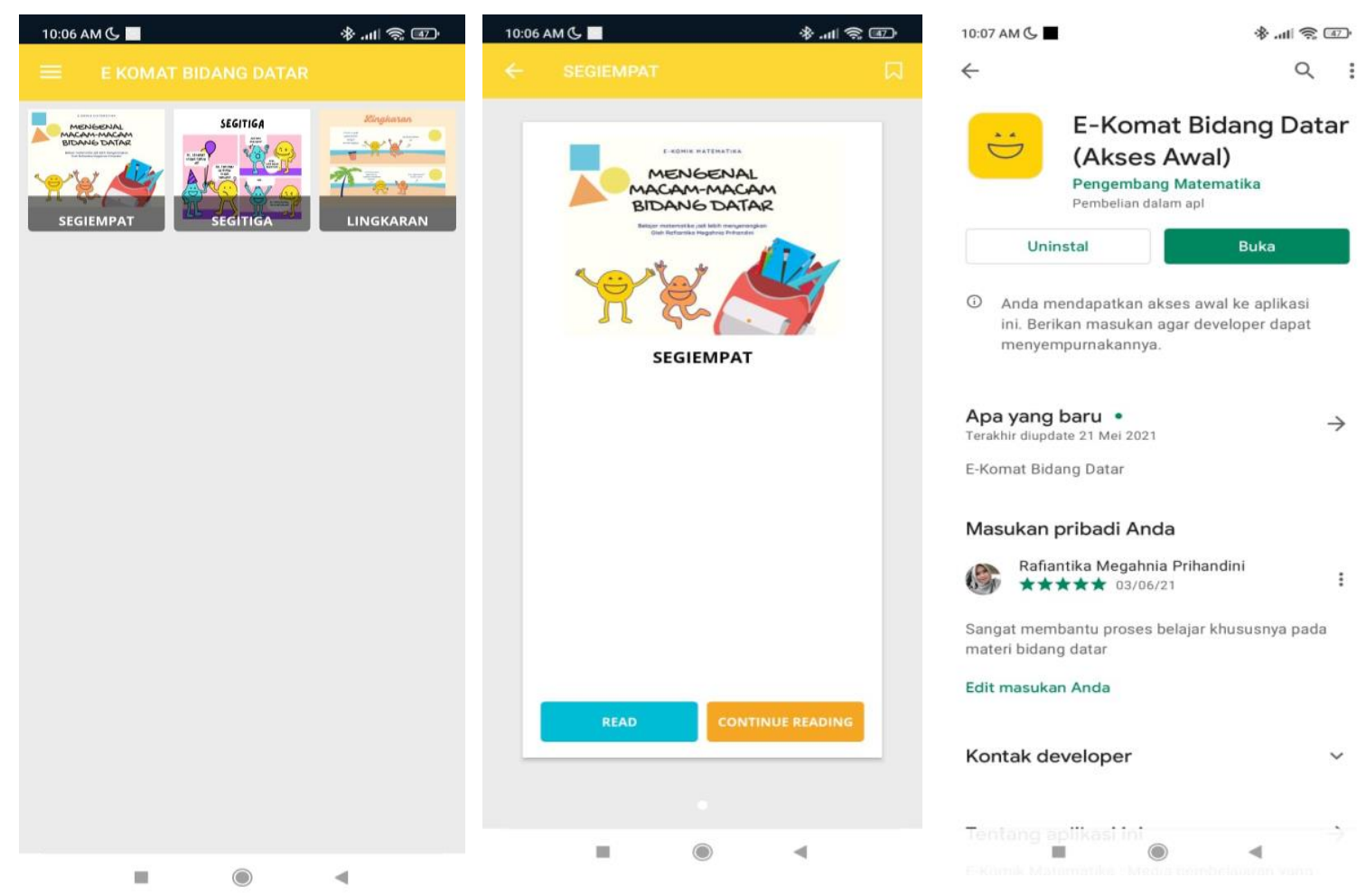

Gambar 2. Tampilan E-Comic tematik berbasis Augmented Reality terintegrasi dengan ICT pada Playstore (Sumber: https://unej.id/EKomat)

E-Comic yang dikembangkan terdiri atas tiga pokok bahasan yaitu segiempat, segitiga, dan lingkaran. Ketiga pokok bahasan tersebut dikembangkan dengan pendeketan Augmented Reality. Sehingga peserta didik bisa mempelajari bidang datar melalui benda benda yang biasa mereka lihat dalam kehidupan sehari - hari. E-Comic dapat diunduh melalui playstore dengan cara menulis E-Komat Bidang Datar pada kolom pencarian. 
Pengembangan E-Comic yang terintegrasi ICT dapat memberi kemudahan bagi peserta didik dalam mengakses dan dapat dipelajari secara online maupun offline.

Selanjutnya peserta pelatihan diberikan arahan cara membuat E-Comic berbasis Augmented Reality menggunakan aplikasi Assemblr. Assemblr adalah platform untuk membuat dan berbagi konten 3D \& Augmented Reality interaktif. Sebelumnya kita membuat project melalui aplikasi tersebut kemudian mempublikasikan hasil yang diperoleh serta mendownload $Q R C o d e$. Selanjutnya $Q R C o d e$ tersebut kita lampirkan pada E-Comic yang dihasilkan. QRCode ini nantinya sebagai marker yang akan terhubung dengan gambar 3D. Adapun cara kerjanya dapat dilihat pada gambar 3.

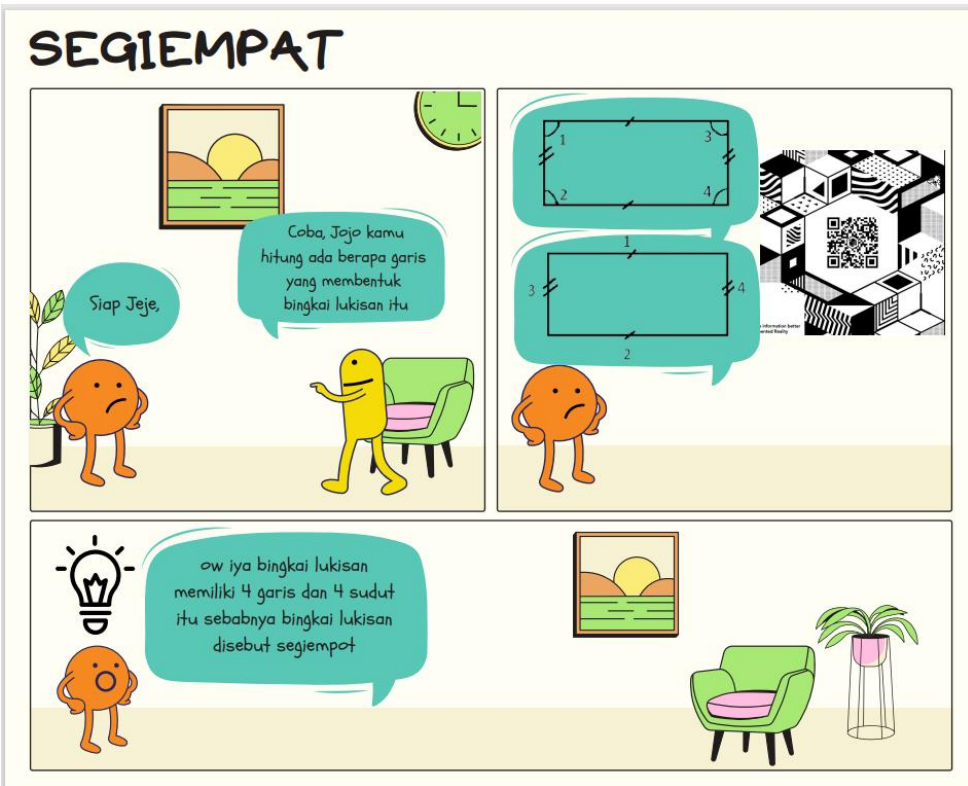

Gambar 3. Tampilan E-Comic dengan QRCode

Buka kembali aplikasi Assemblr lalu pilih scan QRCode yang terlampir pada E-Comic tersebut. Berikut adalah tampilan Augmented Reality dari E-Comic.
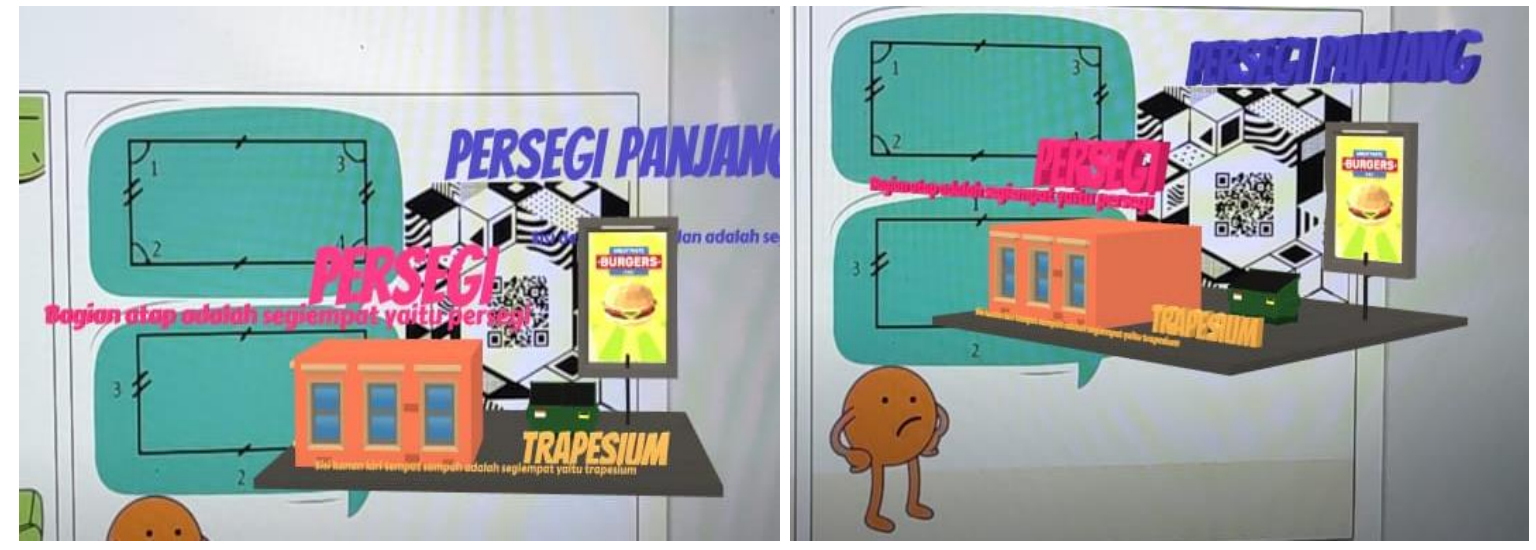

Gambar 4. Tampilan E-Comic tematik berbasis Augmented Reality 
Hal baru ini tentu akan meningkatkan motivasi belajar peserta didik. Selain itu pendidik juga bisa semakin terampil dalam memanfaatkan perangkat lunak dalam proses pembelajaran. Berikut adalah beberapa dokumentasi kegiatan pengabdian di sekolah mitra.
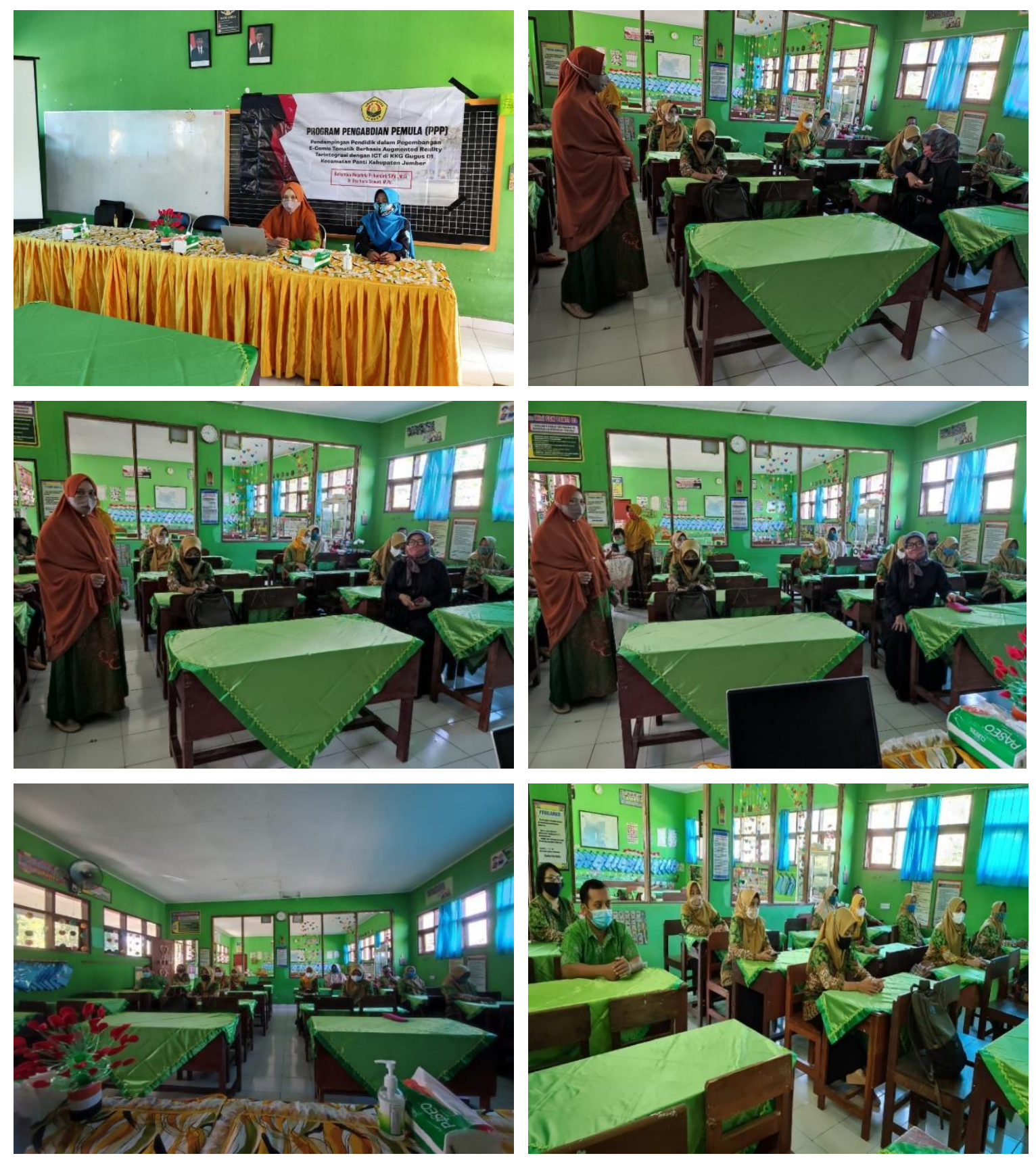

Gambar 5. Dokumentasi Kegiatan Pelaksanaan Pengabdian

Tahap akhir dari model ADDIE adalah tahap evaluation, pada tahap ini tim pengabdian mengevalusi serta menganalisis hasil pendampingan yang telah dilaksanakan. Hal ini dilakukan sebagai bahan evaluasi dalam pelaksanaan pengabdian di sekolah mitra. Melalui evaluasi tersebut, tim pengabdian bisa mengkaji ulang hal - hal yang harus diperbaiki maupun harus ditingkatkan sehingga pelaksanaan pengabdian yang selanjutnya bisa lebih 
baik dari pelaksanaan pengabdian yang sebelumnya. Adapun hasil kuesioner pelaksanaan pengabdian disajikan dalam diagram lingkaran gambar 6 .

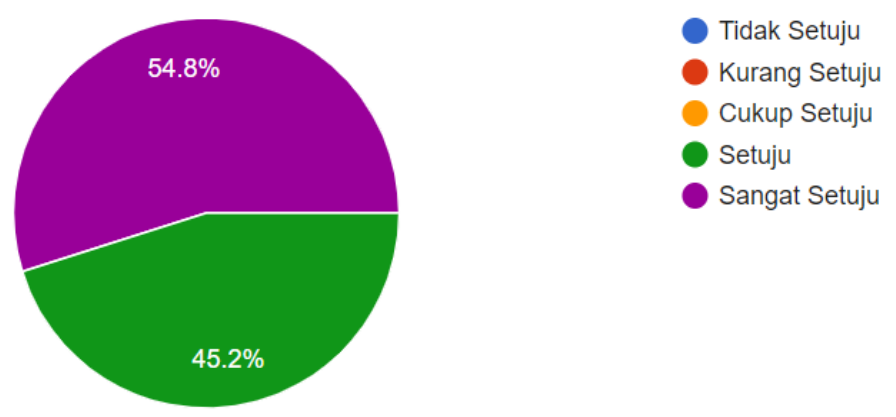

Gambar 6. Kuesioner Mengenai Materi yang Disampaikan (Sumber:

https://unej.id/Kuesioner1)

Berdasarkan form kuesioner yang dibagikan di akhir kegiatan diperoleh hasil bahwa pelaksanaan pengabdian berjalan baik dan lancar. Diperoleh hasil juga bahwa 54,8\% peserta penampingan sangat setuju bahwa materi yang disampaikan menarik dan inspiratif sedangan sebesar 45,2\% setuju bahwa materi yang disampaikan menarik dan inspiratif.

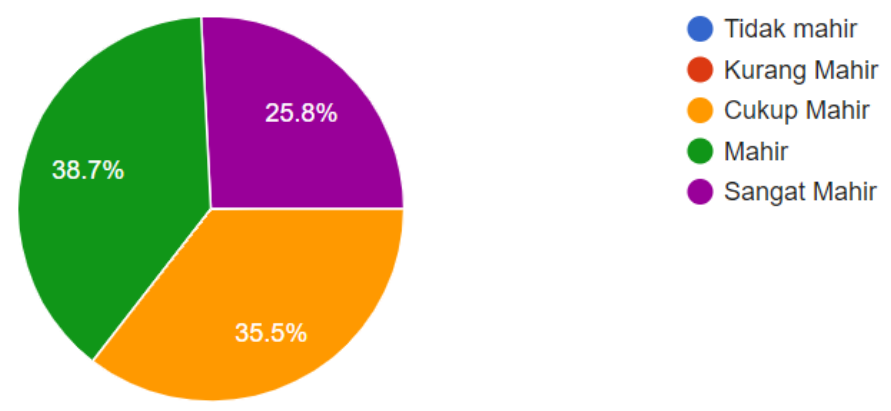

Gambar 7. Kuesioner Keterampilan Peserta Didik dalam Membuat Media Pembelajaran Interaktif Berupa E-Comic dengan Menggunakan Aplikasi Online Maupun Offline (Sumber: https://unej.id/Kuesioner1)

Hasil kuesioner dari pelaksanaan kegiatan pendampingan pendidik dalam pegembangan E-Comic tematik berbasis Augmented Reality terintegrasi dengan ICT adalah $35,5 \%$ cukup mahir, 38,7\% mahir, dan $25,8 \%$ sangat mahir dalam membuat media pembelajaran interaktif berupa E-Comic dengan aplikasi online maupun offline. 


\section{SIMPULAN}

Pelaksanaan pengabdian di KKG Gugus 01 Desa Panti Kecamatan Panti Kabupaten Jember merupakan salah satu upaya untuk memajukan kualitas pendidik di sekolah yang ada pada lingkungan tersebut. Permasalahan yang dihadapi oleh pendidik dalam proses adaptasi pembelajaran online dapat diatasi melalui pendampingan yang telah dilaksanakan oleh tim pengabdian. Pendidik sudah mampu dan terampil dalam menggunakan aplikasi online maupun offline dalam proses melampirkan pengembangan $E$-Comic tematik berbasis Augmented Reality terintegrasi dengan ICT, sehingga dapat menyajikan informasi pembelajaran online yang mudah disampaikan kepada peserta didik dengan berkualitas dan interaktif. Pengembangan E-Comic memiliki keunggulan antara lain dapat menghemat biaya, mudah dalam penyimpanan atau pengarsipannya, lebih praktis untuk dibawa-bawa dan lebih awet dibandingkan dengan media kertas.

\section{UCAPAN TERIMAKASIH}

Penulis mengucapkan terimakasih kepada Universitas jember atas dukungan yang telah diberikan terhadap kegiatan pengabdian kepada masyarakat yang didanai oleh Hibah Pengabdian Pemula tahun 2021 sehingga kegiatan pengabdian dapat berjalan dengan lancar.

\section{DAFTAR PUSTAKA}

Al Hafis, M E, Zaffwan M, dan Nizam A. (2018). Developing Theoretical Framework on Augmented Reality (AR) Comic Using User Experience (UX) Approach. International Journal of Academic Research in Business and Social Sciences, 8(2), 844-851. doi: 10.6007/IJARBSS/v8-i2/4110

Indriasih A, Sumaji, Badjuri, dan Santoso. (2020). Pengembangan E-Comic Sebagai Media Pembelajaran untuk Meningkatkan Kecakapan Hidup Anak Usia Dini. Refleksi Edukatika: Jurnal Ilmiah Kependidikan, Vol. 10 No. 2, 154-162. doi: $\underline{10.24176 / \text { re.v10i2.4228 }}$

Listiaji P, Dewi N R, Taufiq M, Parmin, Atunnisa R, Mahendra E R, dan Darmawan M S. (2020). Pelatihan Interactive Learning Media Based Augmented Reality pada Kelompok Guru IPA SMP Islam Rodlotus Saidiyyah Semarang. Prosiding Seminar Nasional Pembelajaran IPA, 79-85. Diambil dari http://ipa.fmipa.um.ac.id/wpcontent/uploads/Prosiding-SNPI-5-2020-1.pdf

Mustaqim, I. (2017). Pengembangan media pembelajaran berbasis augmented reality. Jurnal Edukasi Elektro, 1(1). doi: 10.21831/jee.v1i1.13267.

Pribadi, Benny A. (2011). Model Desain Sistem Pembelajaran. Jakarta: Dian Rakyat. 
Pelealu, B., Afirianto, T., \& Wardhono, W. (2018). Pengembangan Game Edukasi Mobile Augmented Reality untuk Membantu Pembelajaran Anak dalam Membaca, Menulis, dan Berhitung. Jurnal Pengembangan Teknologi Informasi Dan Ilmu Komputer, 3(2), 1492-1499. Diambil dari https://j-ptiik.ub.ac.id/index.php/j-ptiik/article/view/4414

Simbolon H, Sofiyan, dan Ramadhani D. (2019). Analisis Kesulitaan Belajar Matematika Materi Bangun Datar SD Negeri 7 Langsa. Journal of Basic Education Studies, Vol. 2, $\quad$ No. $\quad 1, \quad 100 \quad-\quad-111 . \quad$ Diambil dari https://ejurnalunsam.id/index.php/jbes/article/view/1594/1424

Widiastuti, D. (2019). Pembuatan Augmented Reality Comic Book "Visualisasi Cara Kerja Web"Sebagai Alternatif Media Pembelajaran. Jurnal TEDC, 10(2), 103-107. Retrieved from https://ejournal.poltektedc.ac.id/index.php/tedc/article/view/179

Y. Cahyaningsih, "Teknologi Augmented Reality pada Promosi Berbasis Android," J. Comput. Sci. Eng., vol. 1, no. 2, pp. 90-115, 2020, doi: $10.36596 /$ jcse.v1i2.60 